\title{
Flood retention in alpine catchments equipped with complex hydropower schemes - A case study of the upper Aare catchment in Switzerland
}

\author{
M. Bieri \& A.J. Schleiss \\ Ecole Polytechnique Fédérale de Lausanne (EPFL), Laboratory of Hydraulic Constructions (LCH), \\ Lausanne, Switzerland \\ F. Jordan \\ e-dric.ch ingénieurs conseils, Epalinges, Switzerland
}

A.U. Fankhauser \& M.H. Ursin

Kraftwerke Oberhasli AG (KWO), Innertkirchen, Switzerland

\begin{abstract}
The simulation of run-off in alpine catchment areas is an important issue for the optimal operation of hydropower plants for normal flow conditions, but also during flood events. A semi-lumped numerical approach combines hydrological modelling and operation of hydraulic elements. It allows simulation of operating mode of complex storage hydropower plants and its impacts on the downstream river system for different scenarios. The modelling of the upper Aare catchment with the Oberhasli hydropower scheme in Switzerland is presented. The effect of the existing reservoirs and their management, taking into account preventive turbining, on flood routing in the Aare River upstream of Lake Brienz is presented for the 2005 and 1987 flood events. The enhancement project KWOplus, which contains a considerable increase of storage volume in the main reservoir as well as in turbining capacity, is estimated.
\end{abstract}

\section{INTRODUCTION}

During the flood event of August 2005, the Aare River upstream Lake Brienz in Switzerland inundated the whole valley between Meiringen and Brienzwiler. The peak flow of $444 \mathrm{~m}^{3} / \mathrm{s}$ is the highest ever measured discharge in Brienzwiler, corresponding statistically to a return period of about 100 years. About half of the river catchment is used for hydropower generation. In order to evaluate the influence of the plant on flood retention, a flow prediction model was developed for the complex Oberhasli hydropower scheme.

For run-off estimations in catchment areas, production and routing of flow are calculated by numerical models. The semi-distributed conceptual code Routing System (Dubois 2005) is appropriate for hydrological forecast in high mountainous catchment areas. It is based on a conceptual glacio-hydrological model (Schaefli et al. 2005). Tri-dimensional rainfall, temperature and evapotranspiration distributions are used for simulating the hydrological processes. The model is able to simulate glacier melt, snow pack constitution and melt, soil infiltration and runoff. The advantage of this object-oriented modelling tool is the integration of flood routing in rivers as well as hydraulic structures such as water intakes, water transfer tunnels, reservoirs with water releasing structures as well as powerhouses. It was successfully applied for several alpine catchments in Switzerland, for example in the Wallis Canton (Jordan 2007).

First the hydrographs of the 1987 and 2005 flood events were accurately simulated. The calibrated and verified model was then used to study the influence of the initial water level in the main reservoirs on the outflow of the catchment area for the flood of 2005 (Bieri et al. 2010). The contribution of the hydraulic scheme to flood routing was analysed through simulations without reservoirs and power plants. For the 2005 flood event, the peak flow without reservoirs was reduced by about $20 \%$. Therefore the retention effect of the Oberhasli hydropower scheme is confirmed. 
Storage hydropower plants have an important effect on flood routing. The potential of active flood management of the Oberhasli scheme is highlighted and discussed for several scenarios, taking into account different flow prediction times, water levels in the four main lakes as well as the enhancement project KWOplus.

\section{THE UPPER AARE RIVER BASIN}

\subsection{Upper Aare River basin}

The upper Aare River, also called Hasliaare, springs in the glaciers of Unteraar and Oberaar at the altitude of $2000 \mathrm{~m}$ a.s.l. and flows nowadays through several artificial reservoirs (Oberaar, Grimsel, Räterichsboden), in which the main part of the water is temporally retained to be turbined in the power plants of Grimsel, Handeck and Innertkirchen. In Innertkirchen the water is given back to the Aare River immediately downstream the confluence with the Gadmerwasser, the river draining the eastern part of the catchment area. After the Aare Gorge the Aare River reaches the main valley of Meiringen and enters Lake Brienz at Brienzwiler. The surface of the upper Aare River basin is $554 \mathrm{~km}^{2}$, where $21 \%$ was glaciated in 2003. The hydrologic regime of the river is therefore glacial. The average annual discharge is $35 \mathrm{~m}^{3} / \mathrm{s}$.

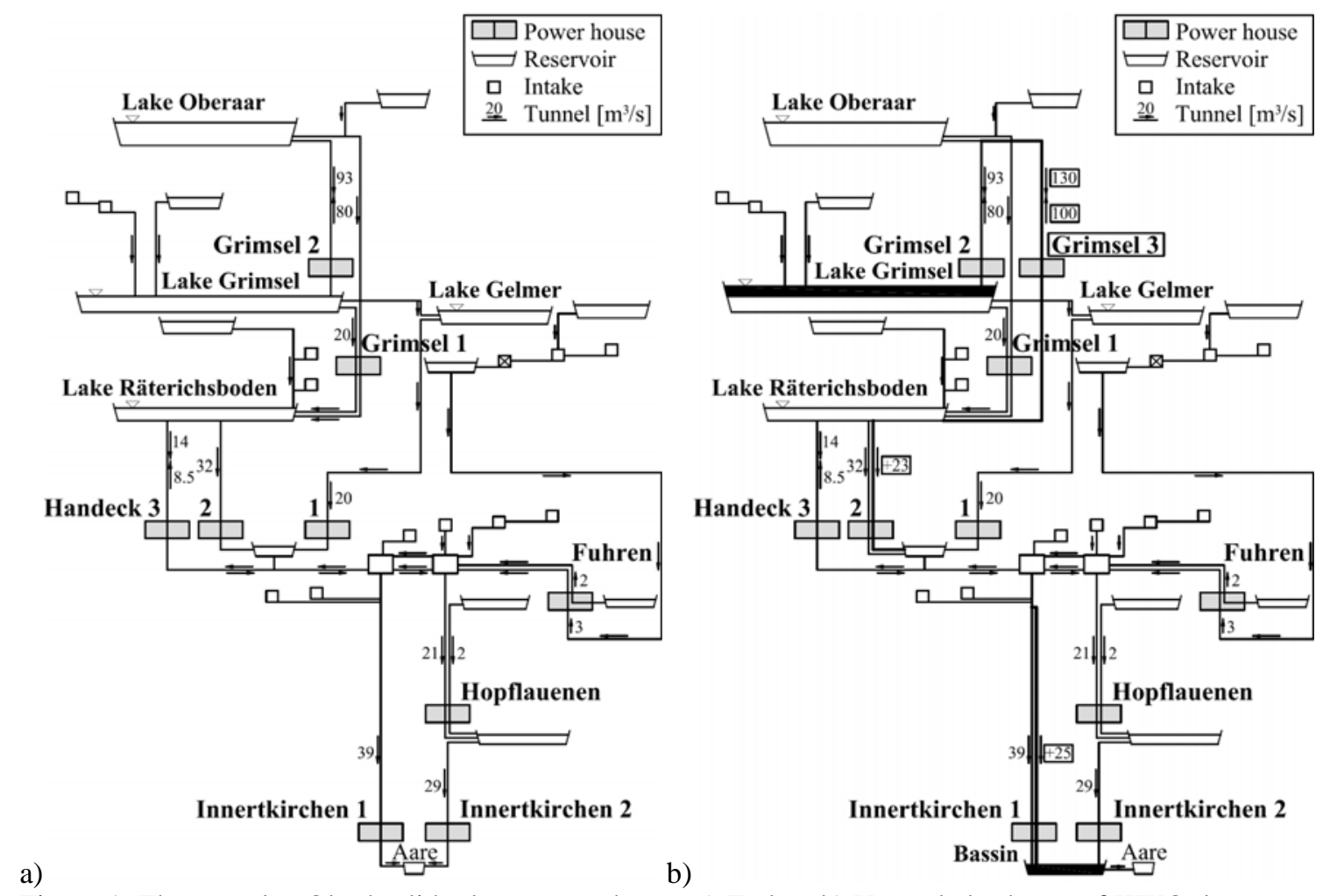

Figure 1. The complex Oberhasli hydropower scheme: a) Today; b) Upgraded scheme of KWOplus.

\subsection{Today's hydropower scheme}

At the end of the $19^{\text {th }}$ century, the area of the Grimsel and Sustenpass was recognized as particularly appropriate for hydropower production. Heavy rainfalls, large retention areas, solid granitic underground as well as substantial slopes provide optimal conditions for a hydropower storage scheme. The first concrete dams were built by the Kraftwerke Oberhasli AG (KWO) between 1925 and 1932. Since then, a complex scheme with nine power plants and eight reservoirs has been constructed (Fig. 1a). The largest reservoirs are the lakes Oberaar $\left(57 \mathrm{Mm}^{3}\right)$, Grimsel $\left(94 \mathrm{Mm}^{3}\right)$, Gelmer $\left(13 \mathrm{Mm}^{3}\right)$ and Räterichsboden $\left(25 \mathrm{Mm}^{3}\right)$.

\subsection{Upgraded Scheme KWOplus}

In the upgrading program KWOplus, a large number of technical, economic and ecological improvements of the actual scheme is foreseen (Fig. 1b). An increase in storage capacity of Lake Grimsel up to $170 \mathrm{Mm}^{3}$ is achieved by a heightening of the dam by $23 \mathrm{~m}$. Power generation can be optimised through a better distribution of the water during the year. 
In parallel, the enhanced power plants Handeck 2 and Innertkirchen 1 will be able to turbine, respectively $23 \mathrm{~m}^{3} / \mathrm{s}$ and $25 \mathrm{~m}^{3} / \mathrm{s}$ more than today, which corresponds to a total power increase of $240 \mathrm{MW}$. The new $600 \mathrm{MW}$ pump storage plant Grimsel 3, using the water from the two existing lakes Oberaar and Räterichsboden, has a turbining capacity of $130 \mathrm{~m}^{3} / \mathrm{s}$ and pumping capacity of $100 \mathrm{~m}^{3} / \mathrm{s}$. The enhancement project KWOplus is planned for construction between 2013 and 2019.

\section{MODELLING}

\subsection{Data sources}

For the simulations several input datasets are needed. The meteorological data are available from the Federal Office of Meteorology and Climatology. On the one hand, temperature and rainfall data are collected every ten minutes by an automatic monitoring network (ANETZ) all over Switzerland. On the other hand, a large number of gauging stations (NIME) measure the daily rainfall. Five stations of the first type and nine of the second are used as input data points in and around the Hasliaare catchment (Fig. 4). The discharge is measured every ten minutes on the Aare River in Brienzwiler by the Federal Office of Environment (BAFU) (Fig. 2).

The KWO made available the hydraulic characteristics of the hydropower scheme, operation rules and historical data from the last 30 years of exploitation. The datasets allow calculation of the inflow of the ten sub-catchments operated by KWO (Fig. 2). Electricity prices are real spot market values from the European Energy Exchange (EEX).

\subsection{Calibration and validation}

The catchment area of the Aare River upstream Lake Brienz is modelled for the configuration of 2003. The 41 sub-catchments are divided in 96 glacial and 243 non glacial elevation bands. For each band, precipitation and temperature are interpolated from the 14 meteorological stations. The basic hydrological formulas as well as the calibration process are explained generically in García Hernández et al. (2007) and specifically in Bieri et al. (2010).

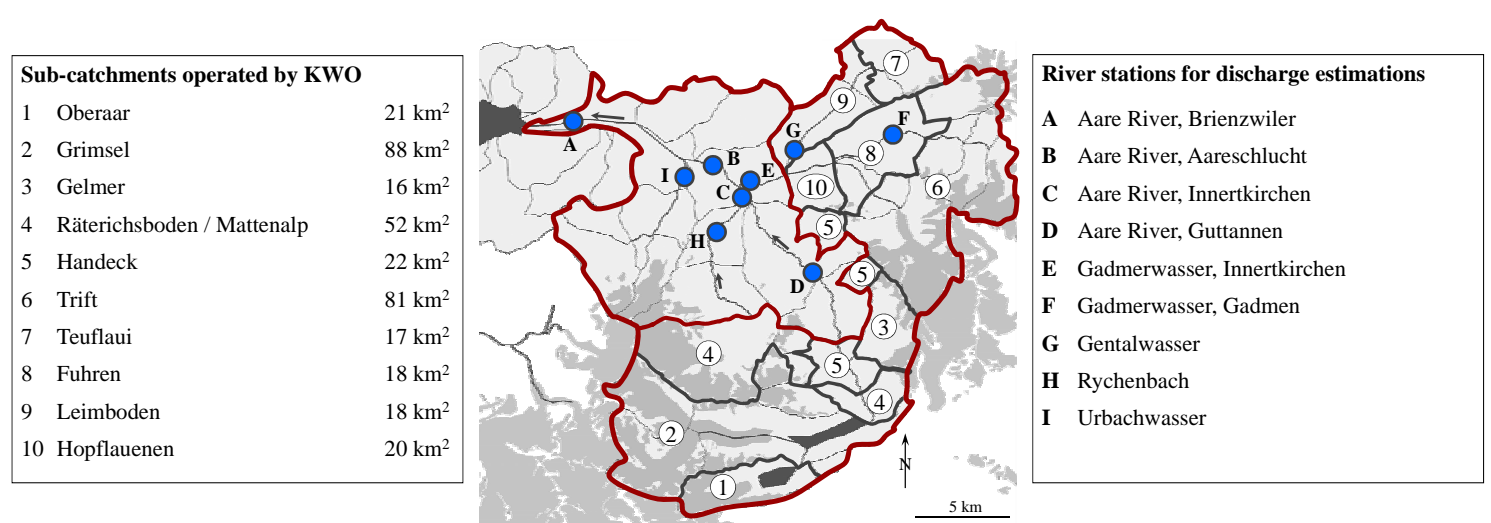

Figure 2. The upper Aare River basin with sub-catchments operated by KWO and river stations used for discharge estimations.

The model was pre-calibrated over a 12 month period for the ten sub-catchments exploited by KWO (Fig. 5a) as well as the natural catchment area upstream of the gauging station of BAFU. In a second step, the model was calibrated by the extreme flood event of August 2005 and validated for the flood of August 1987. The peak flow of the Aare River in 2005, reaching $444 \mathrm{~m}^{3} / \mathrm{s}$ (called measured discharge) is the highest value ever measured in Brienzwiler, corresponding statistically to a return period of about 100 years (Fig. 3a). Because of lateral flooding, the entire discharge could not be measured at the gauging station. A post-analysis of the event, however, allowed an estimation of the real peak and a reconstruction of the hydrograph (called estimated discharge). Flooding is not simulated with Routing System. For this reason, the model was calibrated using the adapted hydrograph with a peak discharge of $520 \mathrm{~m}^{3} / \mathrm{s}$ (Fig. 2). The $1987 \mathrm{flood}$ event produced only insignificant inundation. With minor adaptations of coefficients, the measured and simulated outflow in Brienzwiler are comparable (Fig. 3b). 
The simulations were started at the beginning of the hydrological year in order to obtain parameters independent from the initial conditions. The results were compared to the inflow from the sub-catchments, to the observed outflow in Brienzwiler and to the peak flow estimations in terms of Nash coefficient, water volume ratio $r_{v o l}$ and peak flow ratio $r_{\text {peak }}$.

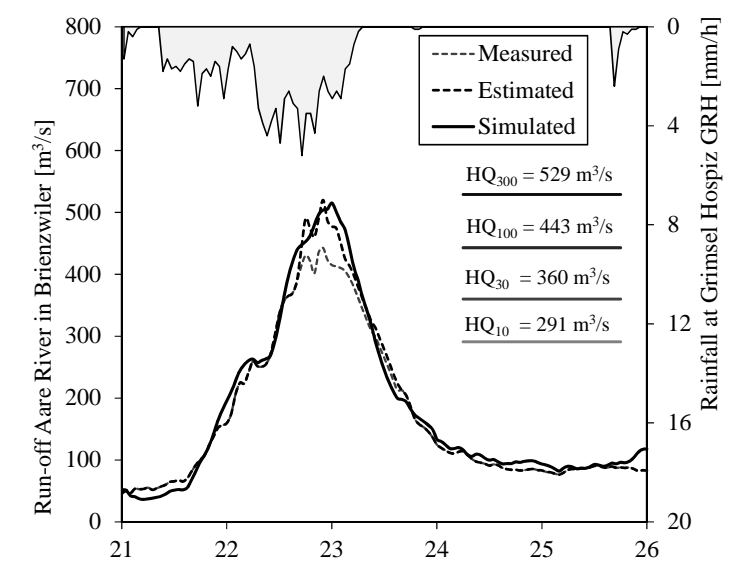

a)

Figure 3. Modelling:

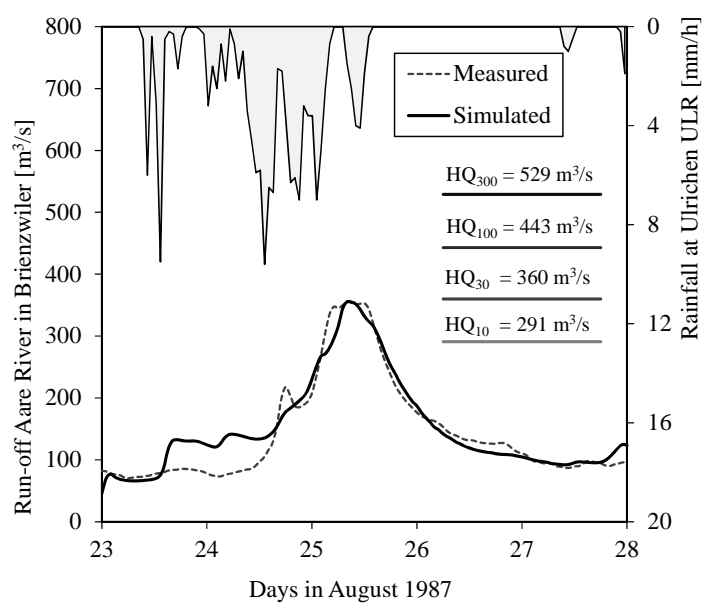

b)

a) Calibration with 2005 flood event $\quad\left(\mathrm{Nash}=0.98, \mathrm{r}_{\mathrm{vol}}=1.03, \mathrm{r}_{\text {peak }}=0.99\right)$;

b) Verification with 1987 flood event $\left(\mathrm{Nash}=0.90, \mathrm{r}_{\mathrm{vol}}=1.05, \mathrm{r}_{\mathrm{peak}}=1.00\right)$.

During calibration and verification of the model, rainfall patterns of all available meteorological stations were compared to generated discharges. As for the Hasliaare catchment, the most relevant Grimsel station was not operational in 1987, therefore the rainfall of Ulrichen is plotted instead (Fig. 3b). Both flood events show coherence between rainfall and discharge. Even if the simulated flood of 1987 generates too high values at an early stage.

\subsection{Scenarios}

A particularity of the two simulated floods is the quite different distribution of rainfall. During the flood event of 2005 (Fig. 4a), maximum rainfall was measured in the north-eastern part of the river basin, where only small reservoirs are situated. For the event of 1987, the gravity centre of the precipitations is in the east (Fig. 4b).

a)

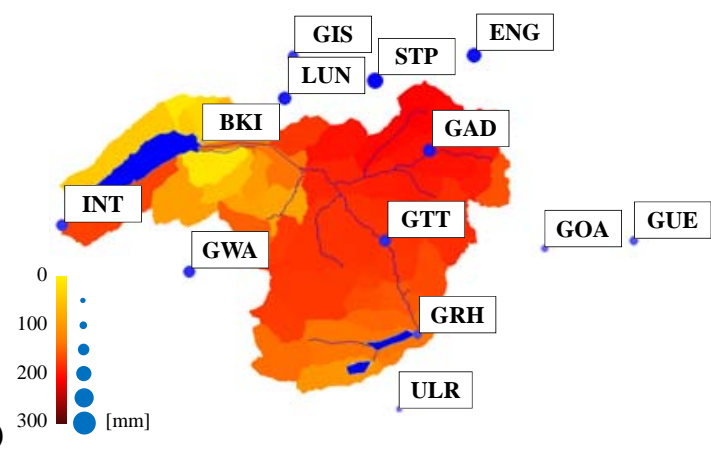

b)

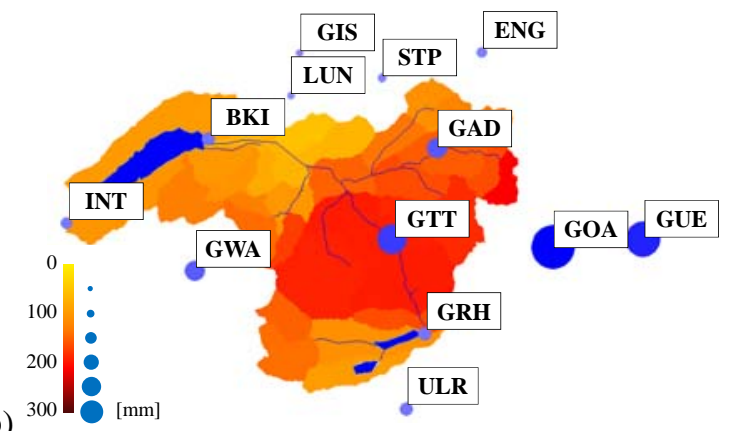

Figure 4. Accumulated rainfall: a) during 2005 flood event (between $21^{\text {st }}$ and $26^{\text {th }}$ of August 2005);

b) during 1987 flood event (between $23^{\text {rd }}$ and $28^{\text {th }}$ of August 1987).

Preventive operation consists of lowering the reservoir levels by turbining or water release by bottom outlets before the flood peak is achieved. By avoiding outflow from the reservoirs during maximal flow period, peak discharge in the downstream river can be reduced. At the end of a flood period, the reservoirs should ideally be filled. For defining the potential of flood retention of today's and the future hydropower scheme by preventive operation, several scenarios had to be tested. The following parameters have been analyzed:

- Two meteorological scenarios are chosen. The 2005 flood event corresponds by definition to a return period of about 100 years. To prove the reliability of the generated potential, a second 100 years event was simulated. To that end, the precipitation of 1987 was multiplied by an overall factor of 1.3, which generates also a flow of about $640 \mathrm{~m}^{3} / \mathrm{s}$ at Brienzwiler for the catchment area without hydropower plants. 
- Three scenarios of filling degrees of the four main reservoirs Oberaar, Grimsel, Räterichsboden and Gelmer were defined, simulated and compared. Scenario 1 corresponds to the real levels of 2005 and 1987. Scenario 2 is a worst case scenario assuming full reservoirs on $18^{\text {th }}$ of August 2005 and $23^{\text {rd }}$ of August 1987. This quite hypothetic case is the upper limit of the sensitivity analysis. Scenario 3 presents average levels in August, calculated over the last 10 years, corresponding to the most likely filling degrees between 70 and $90 \%$.

- Assuming, that flow can be adequately forecasted for a certain prediction time, preventive operation can be optimized. For the given cases, different combinations of prediction times of 24 or 48 hours for the turbine and bottom outlet operation are tested. For a prediction time $\mathrm{X} h$ for the turbines and $\mathrm{Y} h$ for the bottom outlets, the scenario is named $\mathrm{Xh}_{\mathrm{T}} \mathrm{Yh}_{\mathrm{B}}$.

Table 1. Turbine and bottom outlet capacities for preventive operation.

\begin{tabular}{|c|c|c|c|c|}
\hline Power house & from & to & today $\left[\mathrm{m}^{3} / \mathrm{s}\right]$ & KWOplus [m³ $/ \mathrm{s}]$ \\
\hline Grimsel 1, Turbine 1 & Oberaar & Räterichsboden & 8 & 8 \\
\hline Grimsel 1, Turbine 2 & Grimsel & Räterichsboden & 20 & 20 \\
\hline Grimsel 2 & Oberaar & Grimsel & 93 & 93 \\
\hline Grimsel 3 & Oberaar & Räterichsboden & - & 130 \\
\hline Handeck 1 & Gelmer & Handeck & 18 & 18 \\
\hline Handeck 2 & Räterichsboden & Handeck & 32 & 55 \\
\hline Handeck 3 & Räterichsboden & Handeck & 14 & 14 \\
\hline Innertkirchen 1 & Handeck & Aare River & 39 & 64 \\
\hline Bottom outlet & from & to & today $\left[\mathrm{m}^{3} / \mathrm{s}\right]$ & KWOplus [m³/s] \\
\hline Oberaar & Oberaar & Grimsel & 26 & 26 \\
\hline Grimsel & Grimsel & Räterichsboden & 28 & 28 \\
\hline Räterichsboden & Räterichsboden & Handeck & 35 & 35 \\
\hline Gelmer & Gelmer & Handeck & 20 & 20 \\
\hline
\end{tabular}

\subsection{Simulations}

The Oberhasli hydropower scheme comprises a large number of power houses and flood evacuation facilities. Table 1 shows the relevant elements and their admitted capacities for preventive operation. Water coming from the bottom of Lake Oberaar arrives in Lake Grimsel. The only outlet of this reservoir system is the basin of Handeck, where the water is either turbined by Innertkirchen 1 or released directly in the Aare River. The main goal is to retain the water in the reservoirs and to avoid turbining of Innertkirchen 1 during peak flow.

For an autonomous operation mode of the flow control elements (Tab. 1), an algorithm has been developed by e-dric.ch (Fig. 5). For a given prediction time $\Delta \mathrm{t}$, the inflow to the reservoir, the volumes of the upper and lower lake, the flow at the critical point in the downstream river system and the electricity price at the time t' are compared to predefined threshold values. The algorithm considers the priority of the different variables defining the operation mode of each turbine and bottom outlet. The target level curve shows the annual filling cycle of the reservoir. Turbining should be achieved during peak price hours to generate maximum revenue.
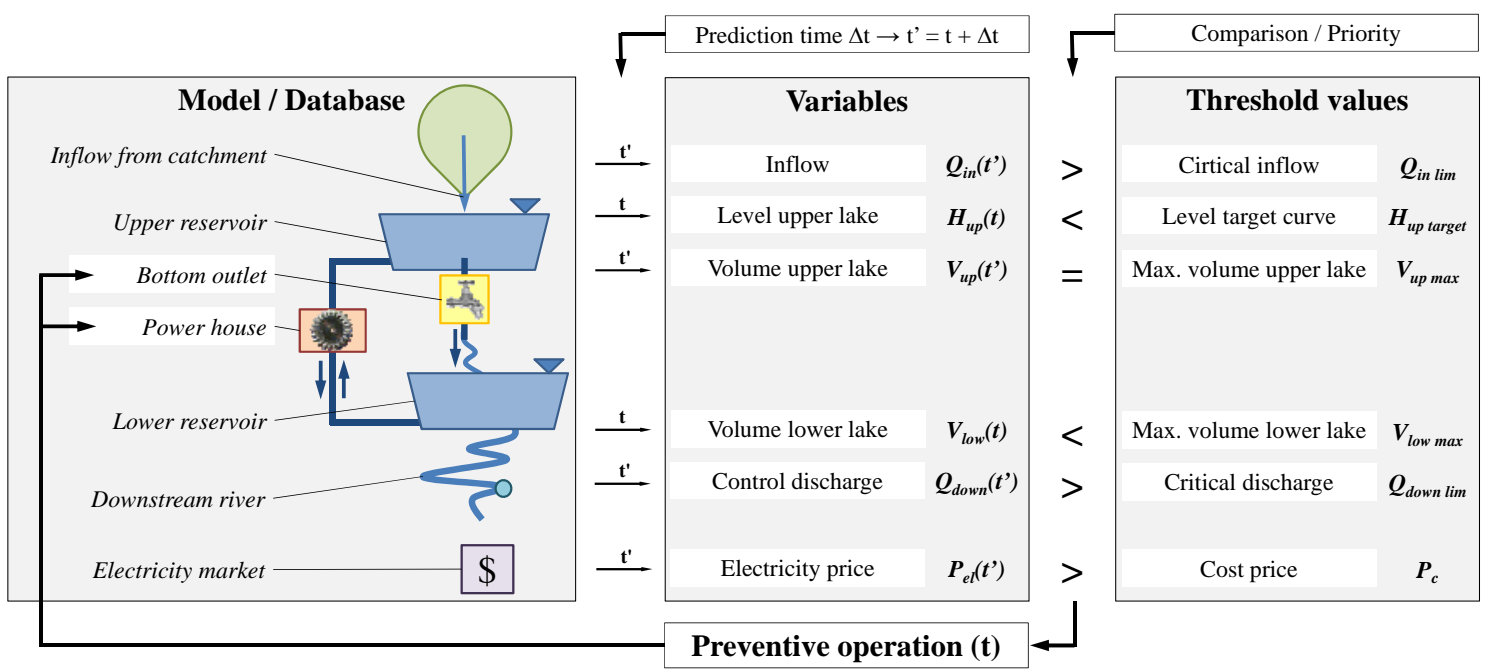

Figure 5. Flow chart of definition process for preventive operation. 


\section{RESULTS AND DISCUSSION}

\subsection{Results}

Tables 2 and 3 show the peak flows and accumulated volumes in Brienzwiler for the two analysed flood events. The model allows the extraction of data for various river stations, turbines, spillways etc. In the following sections, the scenarios are compared for the Aare River at the Brienzwiler gauging station, where a high risk of flooding exists. The critical flood is assumed to be $400 \mathrm{~m}^{3} / \mathrm{s}$.

Table 2. Peak flow of Aare River in Brienzwiler of 2005 and extended 1987 flood event [m³/s].

\begin{tabular}{|c|c|c|c|c|c|c|c|c|c|c|c|}
\hline \multirow{2}{*}{\multicolumn{2}{|c|}{ * }} & \multicolumn{5}{|c|}{ Today's scheme } & \multicolumn{5}{|c|}{ KWOplus } \\
\hline & & $0 \mathrm{~h}_{\mathrm{T}} 0 \mathrm{~h}_{\mathrm{B}}$ & $24 \mathrm{~h}_{\mathrm{T}} 0 \mathrm{~h}_{\mathrm{B}}$ & $24 \mathrm{~h}_{\mathrm{T}} 24 \mathrm{~h}_{\mathrm{B}}$ & $48 \mathrm{~h}_{\mathrm{T}} 0 \mathrm{~h}_{\mathrm{B}}$ & $48 \mathrm{~h}_{\mathrm{T}} 48 \mathrm{~h}_{\mathrm{B}}$ & $0 \mathrm{~h}_{\mathrm{T}} 0 \mathrm{~h}_{\mathrm{B}}$ & $24 \mathrm{~h}_{\mathrm{T}} 0 \mathrm{~h}_{\mathrm{B}}$ & $24 \mathrm{~h}_{\mathrm{T}} 24 \mathrm{~h}_{\mathrm{B}}$ & $48 \mathrm{~h}_{\mathrm{T}} 0 \mathrm{~h}_{\mathrm{B}}$ & $48 \mathrm{~h}_{\mathrm{T}} 48 \mathrm{~h}_{\mathrm{B}}$ \\
\hline \multirow[t]{3}{*}{2005} & 1 & 501 & 507 & 507 & 502 & 502 & 539 & 544 & 508 & 530 & 509 \\
\hline & 2 & 605 & 535 & 518 & 531 & 501 & 539 & 536 & 530 & 531 & 502 \\
\hline & 3 & 513 & 501 & 501 & 507 & 507 & 539 & 535 & 508 & 530 & 509 \\
\hline \multirow[t]{3}{*}{1987} & 1 & 588 & 536 & 470 & 477 & 470 & 520 & 505 & 463 & 505 & 466 \\
\hline & 2 & 620 & 608 & 506 & 608 & 473 & 593 & 529 & 475 & 519 & 466 \\
\hline & 3 & 497 & 484 & 464 & 462 & 477 & 516 & 500 & 463 & 500 & 466 \\
\hline
\end{tabular}

* Scenario 1: Observed level; Scenario 2: Maximum level; Scenario 3: Average level

Table 3. Accumulated volume in Brienzwiler between $21^{\text {st }}$ and $26^{\text {th }}$ of August 2005 and $23^{\text {rd }}$ and $28^{\text {th }}$ of August $1987\left[\mathrm{Mm}^{3}\right]$.

\begin{tabular}{|c|c|c|c|c|c|c|c|c|c|c|c|}
\hline & \multirow[b]{2}{*}{$*$} & \multicolumn{5}{|c|}{ Today’s scheme } & \multicolumn{5}{|c|}{ KWOplus } \\
\hline & & $0 \mathrm{~h}_{\mathrm{T}} 0 \mathrm{~h}_{\mathrm{B}}$ & $24 \mathrm{~h}_{\mathrm{T}} 0 \mathrm{~h}_{\mathrm{B}}$ & $24 \mathrm{~h}_{\mathrm{T}} 24 \mathrm{~h}_{\mathrm{B}}$ & $48 \mathrm{~h}_{\mathrm{T}} 0 \mathrm{~h}_{\mathrm{B}}$ & $48 \mathrm{~h}_{\mathrm{T}} 48 \mathrm{~h}_{\mathrm{B}}$ & $0 \mathrm{~h}_{\mathrm{T}} 0 \mathrm{~h}_{\mathrm{B}}$ & $24 \mathrm{~h}_{\mathrm{T}} 0 \mathrm{~h}_{\mathrm{B}}$ & $24 \mathrm{~h}_{\mathrm{T}} 24 \mathrm{~h}_{\mathrm{B}}$ & $48 \mathrm{~h}_{\mathrm{T}} 0 \mathrm{~h}_{\mathrm{B}}$ & $48 \mathrm{~h}_{\mathrm{T}} 48 \mathrm{~h}_{\mathrm{B}}$ \\
\hline \multirow[t]{3}{*}{2005} & 1 & 113 & 114 & 114 & 114 & 114 & 122 & 123 & 123 & 125 & 125 \\
\hline & 2 & 150 & 153 & 154 & 152 & 156 & 146 & 148 & 150 & 150 & 155 \\
\hline & 3 & 128 & 129 & 129 & 127 & 128 & 126 & 125 & 125 & 131 & 125 \\
\hline \multirow[t]{3}{*}{1987} & 1 & 83 & 83 & 84 & 81 & 87 & 72 & 72 & 72 & 72 & 74 \\
\hline & 2 & 95 & 92 & 94 & 93 & 94 & 90 & 90 & 91 & 88 & 90 \\
\hline & 3 & 73 & 74 & 74 & 76 & 75 & 71 & 72 & 72 & 72 & 74 \\
\hline
\end{tabular}

* Scenario 1: Observed level; Scenario 2: Maximum level; Scenario 3: Average level

\subsection{Influence of initial reservoir level}

The initial level in the main reservoirs is an important parameter, which influences directly the outflow of the system. Maximum reservoir levels without preventive operation produces $30 \%$ (Fig. 6a) to $17 \%$ (Fig. 6b) higher flows in the Aare River than the average August reservoir levels, which generate a discharge of $500 \mathrm{~m}^{3} / \mathrm{s}$ for both events, due to flood routing in the reservoirs. The accumulated volumes are also higher (Tab. 3), because of important flood release by the spillways, especially during increasing flows. Both downstream hydropower plants Innertkirchen 1 and 2 are operating on their maximum capacity.
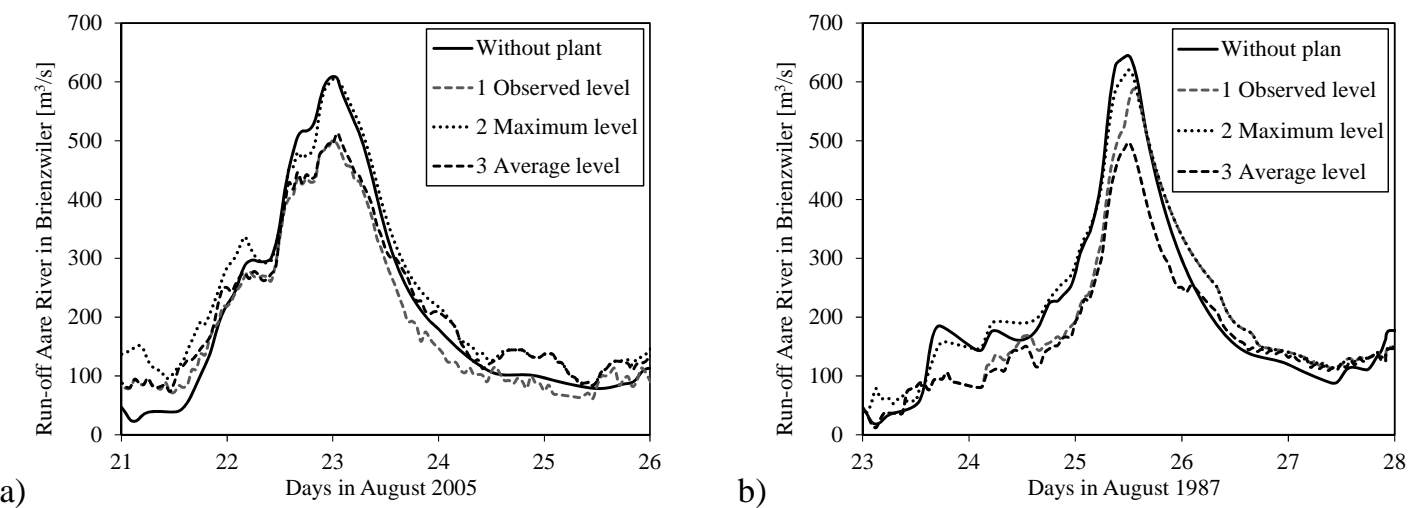

Figure 6. Hydrographs of 2005 (a) and extended 1987 (b) flood for different initial reservoir levels for today's scheme. 


\subsection{Preventive operation}

Preventive emptying of reservoirs leads to lower discharge in the Aare River. The peak flow of the 2005 flood could be reduced considerably from $605 \mathrm{~m}^{3} / \mathrm{s}$, without preventive operation, to values between $535 \mathrm{~m}^{3} / \mathrm{s}$ for $24 \mathrm{~h}_{\mathrm{T}} 0 \mathrm{~h}_{\mathrm{B}}$ and $500 \mathrm{~m}^{3} / \mathrm{s}$ for $48 \mathrm{~h}_{\mathrm{T}} 48 \mathrm{~h}_{\mathrm{B}}$ (Tab. 2 and Fig. $7 \mathrm{a}$ ). For the extended 1987 flood, the preventive turbining scenarios are less efficient than the ones with bottom outlet operations (Tab. 2 and Fig. 7b). The reason is the lack of capacity of Innertkirchen 1, which does not allow the timely emptying of Lake Räterichsboden. The cumulated volumes are similar for all hydrographs (Tab. 3).
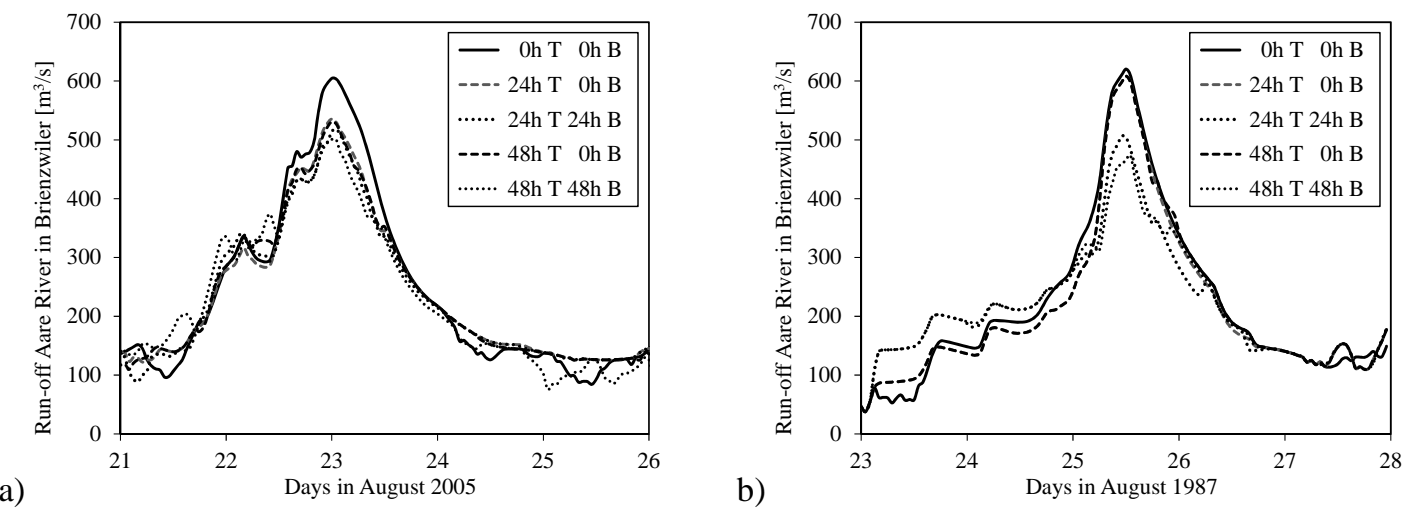

Figure 7. Hydrographs of 2005 (a) and extended 1987 (b) flood for different prediction times for preventive operation for maximum initial reservoir levels for today's scheme ( $\mathrm{T}$ = turbine; $\mathrm{B}=$ bottom outlet).

\subsection{Potential of upgraded scheme KWOplus}

In spite of the $0 \mathrm{~h}_{\mathrm{T}} 0 \mathrm{~h}_{\mathrm{B}}$ scenario for the extended 1987 flood, where results are not as pronounced, the upgraded scheme KWOplus shows for all other scenarios with maximum initial reservoir levels much lower peak discharge than today's scheme, namely between 500 and $540 \mathrm{~m}^{3} / \mathrm{s}$ for 2005 (Fig. 8a) and 470 and $530 \mathrm{~m}^{3} / \mathrm{s}$ for 1987 (Fig. 8b). Considering scenarios 1 and 3, the maximum discharge for a flood with a return period of 100 years is $550 \mathrm{~m}^{3} / \mathrm{s}$. The increased capacities of Handeck 2 and Innertkirchen 1 allow efficient water release in the prepeak period, creating sufficient storage volume for avoiding turbining during peak flow.
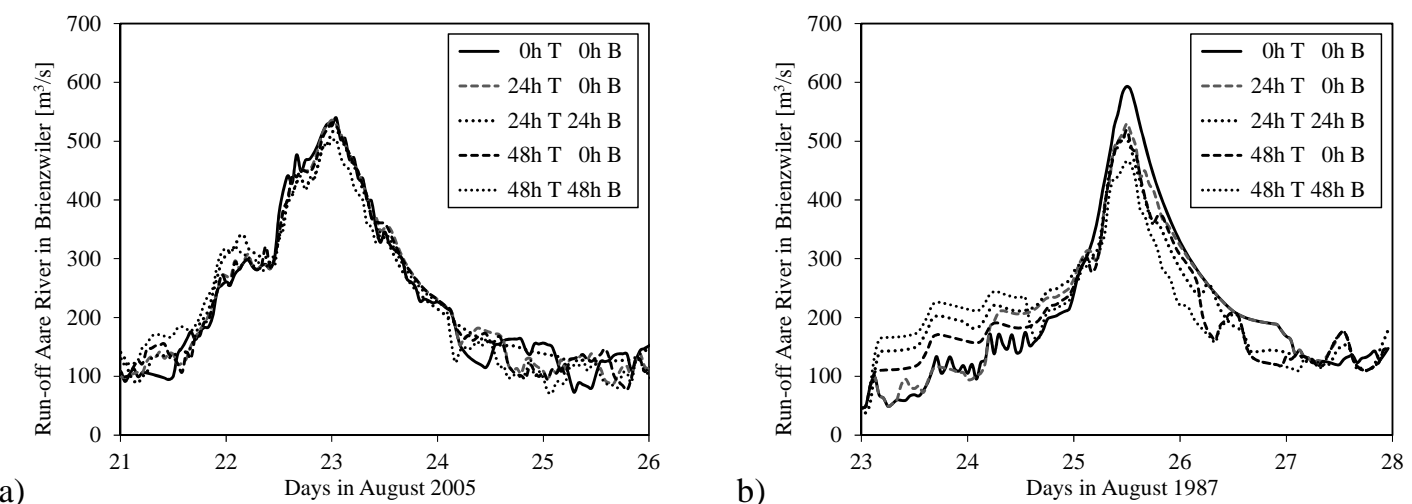

Figure 8. Hydrographs of 2005 (a) and extended 1987 (b) flood for different prediction times for preventive operation for maximum initial reservoir levels for KWOplus ( $\mathrm{T}=$ turbine; $\mathrm{B}=$ bottom outlet).

\section{CONCLUSIONS}

The presented model is robust and gives satisfying results for the observed flood events. The simulated hydrographs conform to the observed ones. By taking into account the influence of a hydropower scheme, different scenarios could be analysed. Constraints and initial conditions as well as input data can be adapted and their effects evaluated.

Even for today's scheme, preventive operation for lowering the reservoir levels can reduce the flood peak in the Aare River. Higher flood peak reduction is achieved by using not only the turbines but also the bottom outlets of the dams. Taking into account the upgraded scheme KWOplus, the maximum flood peak with a return period of 100 years is $530 \mathrm{~m}^{3} / \mathrm{s}$ for most of the simulated scenarios, close to the observed value during 2005 flood event of $520 \mathrm{~m}^{3} / \mathrm{s}$. 
Even today's Oberhasli hydropower scheme has a retention effect of its reservoirs. Further simulations will be performed for flood scenarios with a return period of 300 years, the maximum event relevant for flood protection in this area.

An active flood management system, in collaboration with the local authorities, could reduce the risk of flooding. Therefore the model could be applied for real time simulations by using weather forecast data as input. An agreement between the plant owner and authorities, including a decision making strategy, would define the measures to be taken in the event of defined threshold values being exceeded during a flood.

\section{REFERENCES}

Bieri, M., Schleiss, A.J. \& Fankhauser, A. 2010. Modelling and simulation of floods in alpine catchments equipped with complex hydropower schemes. In A. Dittrich et al. (eds.), River Flow; Proc. intern. symp., Braunschweig, 8-10 September 2010. Karlsruhe: Bundesanstalt für Wasserbau.

Dubois, J. 2005. Simulation des systèmes hydrauliques et hydrologiques complexe : Routing System II. In A. Schleiss (ed.), Communication 21 du Laboratoire de Constructions Hydrauliques. Lausanne: EPFL.

García Hernández, J., Jordan, F., Dubois, J. \& Boillat, J.-L. 2007. Routing System II: Flow modelling in hydraulic systems. In A. Schleiss (ed.), Communication 32 du Laboratoire de Constructions Hydrauliques. Lausanne: EPFL.

Jordan, F., García Hernández, J., Dubois, J. \& Boillat, J.-L. 2008. MINERVE: Modélisation des intempéries de nature extrême du Rhône valaisan et de leurs effets. In A. Schleiss (ed.), Communication $38 d u$ Laboratoire de Constructions Hydrauliques. Lausanne : EPFL.

Schaefli, B., Hingry, B., Niggli, M. \& Musy, A. 2005. A conceptual glacio-hydrological model for high mountainous catchments. In Hydrology and Earth System Sciences 9: 95-109. 